\title{
LEPR Gene
}

National Cancer Institute

\section{Source}

National Cancer Institute. LEPR Gene. NCI Thesaurus. Code C24545.

This gene plays a role in transcriptional regulation via activation of the STAT signal

transduction pathway. The gene is also involved in the regulation of adipose tissue or lipid metabolism. 